\title{
28 Research Square \\ The authors have requested that this preprint be removed from Research Square.
}

Keywords:

Posted Date: April 8th, 2021

DOI: https://doi.org/10.21203/rs.3.rs-371362/v1

License: (c) (i) This work is licensed under a Creative Commons Attribution 4.0 International License.

Read Full License

Version of Record: A version of this preprint was published at Archives of Women's Mental Health on July 31st, 2021. See the published version at https://doi.org/10.1007/s00737-021-01164-x. 


\section{Abstract}

The authors have requested that this preprint be removed from Research Square. 